Measurement, Vol.12 No. 2 : 192 - 205

Desember 2018

P-ISSN 2252-5394

\title{
DAMPAK IMPLEMENTASI STANDAR AKUNTANSI PEMERINTAH BERBASIS AKRUAL TERHADAP AKUNTABILITAS KEUANGAN DAERAH WILAYAH SUMATERA
}

\section{THE IMPACT OF IMPLEMENTATION OF ACCRUAL-BASED GOVERNMENT ACCOUNTING STANDARDS ON THE REGIONAL FINANCIAL ACCOUNTABILITY OF THE SUMATRA REGION}

\author{
Ravika Permata Hati ${ }^{1}$ \\ ${ }^{I}$ (Akuntansi, Ekonomi, Universitas Riau Kepulauan, Indonesia) \\ ${ }^{1}$ ravika@fekon.unrika.ac.id
}

\begin{abstract}
Abstrak
Penelitian ini bertujuan untuk mengujiapakah implementasi SAP berbasis akrual berpengaruh signifikan terhadap akuntabilitas keuangan daerah yang dilihat dengan menggunakan Rasio Efisiensi (OROE), Rasio Pemanfaatan Aktiva (AT/ROA), Rasio Likuiditas (CR), dan Rasio Solvabilitas (LA) Keuangan Daerah. Penelitian ini menggunakan metode analisis data dengan pendekatan kuantitatif, dengan menggunakan analisis regresi sederhana untuk menguji apakah implementasi SAP berbasis akrual memiliki dampak pada Akuntabilitas Keuangan Daerah. Penelitian ini menggunakan data Laporan Keuangan Daerah yang dipublikasikan melalui website www.bpk.go.id. Teknik pengambilan sampel yang digunakan adalah purposive sampling.Dari hasil analisis data dapat disimpulkan: (1) Implementasi akuntansi berbasis akrual tidak berpengaruh terhadap OROE. (2) Implementasi akuntansi berbasis akrual berpengaruh negatif terhadap ROA. (3) Implementasi akuntansi berbasis akrual berpengaruh positif terhadap CR. (4) Implementasi akuntansi berbasis akrual berpengaruh negatif terhadap LA.

Kata Kunci ; Standar Akuntansi Pemerintah; Berbasis Akrual; Akuntabilitas Keuangan Daerah; Rasio Efisiensi; Rasio Pemanfaatan Aktiva; Rasio Likuiditas; Rasio Solvabilitas

Abstract

This study aims to examine whether the accrual-based SAP implementation has a significant effect on regional financial accountability seen using the Efficiency Ratio (OROE), Asset Utilization Ratio (AT / ROA), Liquidity Ratio (CR), and Solvability Ratio (LA) Regional Finance.This study uses a method of data analysis with a quantitative approach, using simple regression analysis to test whether the accrual-based SAP implementation has an impact on Regional Financial Accountability. This study uses data from the Regional Financial Statements published through the website www.bpk.go.id. The sampling technique used was purposive sampling.The results of data analysis it can be concluded: (1) Implementation of accrual-based accounting has no effect on OROE. (2) Implementation of accrualbased accounting has a negative effect on ROA. (3) Implementation of accrual-based accounting has a positive effect on CR. (4) Implementation of accrual-based accounting has a negative effect on LA.
\end{abstract}

Keywords ; Government Accounting Standard; Accrual Based; Regional Financial Accountability;Efficiency Ratio; Asset Ratio; Liquidity Ratio; Solvability Ratio 


\section{PENDAHULUAN}

\section{Latar Belakang Masalah}

Reformasi keuangan daerah telah terjadi ditandai dengan diberlakukannya UU No. 22, Tahun 1999 tentang Pemerintahan Daerah dan UU No. 25, Tahun 1999 tentang Perimbangan Keuangan antara Pemerintahan Pusat dan Daerah. Salah satu semangat reformasi keuangan daerah adalah dilakukannya pertanggungjawaban keuangan oleh pemerintah daerah dan penilaian kinerja keuangan daerah agar dapat diketahui sejauh mana pemerintah daerah mampu melaksanakan keuangannya. Menurut Fanani, Mudyanti \& Affandi (2008) konflik yang dapat timbul pada sektor publik adalah kadar pengungkapan informasi laporan keuangan. Pengguna laporan keuangan berharap dapat memperoleh semua informasi yang mereka butuhkan dari laporan keuangan.

Laporan keuangan memuat informasi yang relevan mengenai posisi keuangan dan seluruh transaksi yang dilakukan oleh suatu entitas pelaporan selama satu periode pelaporan.Laporan keuangan terutama digunakan untuk membandingkan realisasi pendapatan, belanja, transfer, dan pembiayaan dengan anggaran yang ditetapkan, menilai kondisi keuangan, mengevaluasi efektifitas dan efisiensi suatu entitas pelaporan, dan membantu menentukan ketaatannya terhadap peraturan perundangan.

Laporan keuangan pemerintah harus menyediakan informasi yang dapat dipakai oleh pengguna laporan keuangan untuk menilai akuntabilitas pemerintah dalam membuat keputusan ekonomi, sosial, dan politik.Dalam Vivanews (2008) diungkapkan bahwa Badan Pemeriksa Keuangan (BPK) menilai akuntabilitas keuangan daerah belum menunjukkan perbaikan sama sekali.

Selama empat tahun sejak 2004-2007 tidak ada perubahan berarti. Kondisi buruk ini, dapat dilihat dari persentase Laporan Keuangan Pemerintah Daerah yang mendapatkan opini Wajar Tanpa Pengecualian dan Wajar Dengan Pengecualian.Bahkan selama kurun waktu 2004-2007 tersebut nilainya semakin menurun setiap tahun. Persentase Laporan Keuangan Pemerintah Daerah 2004 yang mendapat penilaian Wajar Tanpa Pengecualian, dari semula 7 persen menjadi 5 persen pada 2006 dan satu persen pada 2007. Sebaliknya, Laporan Keuangan Pemerintah Daerah dengan opini Tidak Memberi Pendapat semakin meningkat dari 2 persen pada 2004 menjadi 17 persen pada 2007. Untuk periode yang sama opini Tidak Wajar naik dari 3 persen menjadi 19 persen.

Menurut Ammon (2007) Serangkaian pengukuran kinerja keuangan yang baik merupakan alat penting untuk membangun akuntabilitas. Nilai pada pengukuran kinerja yang dilaporkan secara luas untuk tujuan akuntabilitas. Chan \&Gao (2007) menyatakan bahwa pengukuran kinerja akan membantu meningkatkan akuntabilitas publik. Salah satu alat untuk menganalisis kinerja keuangan pemerintah daerah adalah dengan melakukan analisis rasio keuangan.

Dalam rangka mewujudkan tujuan diatas, Pemerintah mengeluarkan UndangUndang Nomor 17 Tahun 2003 tentang Keuangan Negara yang menegaskan bahwa setiap instansi pemerintah, baik pemerintah pusat maupun pemerintah daerah harus menerapkan akuntansi berbasis akrual yang dimulai tahun anggaran 2008. Penerapan akuntansi berbasis akrual merupakan salah satu reformasi dibidang akuntansi pemerintahan. 
Menurut PSAP 01 Basis akrual adalah basis akuntansi yang mengakui pengaruh transaksi dan peristiwa lainnya pada saat transaksi dan peristiwa itu terjadi, tanpa memperhatikan saat kas atau setara kas diterima atau dibayar.Menurut Cudia (2008) metode akrual mencatat pendapatan dan beban dalam satu periode akuntansi dimana dengan mempertimbangkan saat diperoleh dan terjadi.

Menurut Champoux (2006), walaupun akuntansi akrual disukai oleh sektor swasta untuk beberapa dekade, namun secara relatif baru-baru ini pemerintah nasional itu mulai untuk dengan serius mempertimbangkan memanfaatkan ukuran akrual untuk penganggaran dan pelaporan keuangan. Alasan memanfaatkan akuntansi akrual, karena secara umum sistem akrual dilihat sebagai cara meningkatkan transparansi anggaran, terutama dalam kaitannya dengan kemampuan untuk menghitung asset jangka panjang dan kewajiban, dan juga sebagai alat untuk meningkatkan efisiensi pemerintah melalui manajemen berbasis kinerja.

\section{Rumusan Masalah}

Berdasarkan latar belakang di atas, maka rumusan masalah dari penelitian ini adalah

1. Apakah implementasi akuntansi berbasis akrual pada Sistem Akuntansi Pemerintah berpengaruh terhadap Rasio Efisiensi (OROE)?

2. Apakah implementasi akuntansi berbasis akrual pada Sistem Akuntansi Pemerintah berpengaruh terhadap Rasio Pemanfaatan Aktiva (AT/ROA)?

3. Apakah implementasi akuntansi berbasis akrual pada Sistem Akuntansi Pemerintah berpengaruh terhadap Rasio Likuiditas (CR)?
4. Apakah implementasi akuntansi berbasis akrual pada Sistem Akuntansi Pemerintah berpengaruh terhadap Rasio Solvabilitas (LA)?

\section{Tujuan Penelitian}

Berdasarkan rumusan masalah di atas, maka tujuan penelitian ini adalah untuk memberikan bukti empiris bahwa

1. terdapat pengaruh yang signifikan antara implementasi akuntansi berbasis akrual pada Sistem Akuntansi Pemerintah terhadap Rasio Efisiensi (OROE)

2. terdapat pengaruh yang signifikan antara implementasi akuntansi berbasis akrual pada Sistem Akuntansi Pemerintah terhadap Rasio Pemanfaatan Aktiva (TA/ROA)

3. terdapat pengaruh yang signifikan antara implementasi akuntansi berbasis akrual pada Sistem Akuntansi Pemerintah terhadap Rasio Likuiditas (CR)

terdapat pengaruh yang signifikan antara implementasi akuntansi berbasis akrual pada Sistem Akuntansi Pemerintah terhadap Rasio Solvabilitas (LA)

\section{Landasan Teori}

\section{Akuntansi Berbasis Akrual}

Menurut PSAP 01 Basis akrual adalah basis akuntansi yang mengakui pengaruh transaksi dan peristiwa lainnya pada saat transaksi dan peristiwa itu terjadi, tanpa memperhatikan saat kas atau setara kas diterima atau dibayar. Menurut Cudia (2008) metode akrual mencatat pendapatan dan beban dalam satu periode akuntansi dimana dengan mempertimbangkan saat diperoleh dan terjadi.

Menurut Mustofa (2006) Akuntansi berbasis akrual berarti suatu basis akuntansi 
di mana transaksi ekonomi dan peristiwaperistiwa lain diakui dan dicatat dalam catatan akuntansi dan dilaporkan dalam periode laporan keuangan pada saat terjadinya transaksi tersebut, bukan pada saat kas atau ekuivalen kas diterima atau dibayarkan. Akuntansi berbasis akrual ini banyak dipakai oleh institusi sektor non publik dan lembaga lain yang bertujuan mencari keuntungan. International Monetary Fund (IMF) sebagai lembaga kreditur menyusun Government Finance Statistics (GFS) yang di dalamnya menyarankan kepada negara-negara debiturnya untuk menerapkan akuntansi berbasis akrual dalam pembuatan laporan keuangan.

\section{Akuntabilitas Keuangan Daerah}

Akuntabilitas merupakan salah satu unsur pokok perwujudan Good Governance yang saat ini sedang diupayakan di Indonesia. Pemerintah diminta untuk melaporkan hasil dari program yang telah dilaksanakan sehingga masyarakat dapat menilai apakah pemerintah telah bekerja dengan ekonomis, efisien dan efektif (Sadjiarto, 2000).

Menurut Barrett (2004) akuntabilitas merupakan hubungan berdasarkan kewajban untuk menunjukkan, meninjau ulang dan mempertanggungjawabkan kinerja, yang hasilnya sesuai harapan yang telah disepakati. Budiardjo dalam Krina (2003) mendefinisikan akuntabilitas sebagai pertanggungjawaban pihak yang diberi mandat untuk memerintah kepada mereka yang memberi mandat itu. Akuntabilitas bermakna pertanggungjawaban dengan menciptakan pengawasan melalui distribusi kekuasaan pada berbagai lembaga pemerintah sehingga mengurangi penumpukkan kekuasaan sekaligus menciptakan kondisi saling mengawasi (checks and balances system). Lembaga pemerintahan yang dimaksud adalah eksekutif (presiden, wakil presiden, dan kabinetnya), yudikatif (MA dan sistem peradilan) serta legislatif (MPR dan DPR). Peranan pers yang semakin penting dalam fungsi pengawasan ini menempatkannya sebagai pilar keempat.

Dalam penelitian ini menggunakan konsep akuntabilitas kinerja dalam mengukur akuntabilitas keuangan daerah. Menurut Solihin (2007) akuntabilitas kinerja adalah perwujudan suatu instansi pemerintah untuk mempertanggungjawabkan keberhasilan atau kegagalan pelaksanaan misi organisasi dalam mencapai tujuan-tujuan dan sasaran-sasaran yang telah ditetapkan melalui alat pertanggungjawaban secara periodik. Adapun indikator minimal akuntabilitas adalah sebagai berikut.

1. Adanya kesesuaian antara pelaksanaan dengan standar prosedur pelaksanaan.

2. Adanya sanksi yang ditetapkan atas kesalahan atau kelalaian dalam pelaksanaan kegiatan.

3. Adanya output dan outcome yang terukur.

\section{Level Implementasi Akuntansi Berbasis Akrual}

Pengenalan akuntansi akrual merupakan perubahan signifikan pada tradisi manajemen sektor publik. Guthrie (1998) menyatakan bahwa adopsi akuntansi akrual memerlukan adanya perubahan teknologi informasi dan budaya departemen/organisasi. Adopsi terhadap praktek baru memerlukan adaptasi.

Menurut Windels \& Christiaens (2007) accounting index yang dimodifikasi dari penelitian Christiaens (1999) terdiri dari 9 komponen utama yang mencakup 90 elemen. Komponen-komponen tersebut terdiri dari completeness, valuation, cut-off, classification, mechanical accuracy, time lines, adequacy and usefulness, formalistic requirement, disclosure. Dalam penelitian ini 
level adopsi akuntansi berbasis akrual diukur dengan memodifikasi elements of compliance index (Christiaens, 1999) dan elements of accounting index (Windels \& Christiaens, 2007) yang disesuaikan dengan kondisi di Indonesia dengan berpedoman pada SAP dan datanya dapat di akses atau tersedia di Laporan Keuangan Pemerintah Daerah.

\section{Hubungan Pengukuran Kinerja dengan Akuntabilitas}

Serangkaian pengukuran kinerja keuangan yang baik merupakan alat penting untuk membangun akuntabilitas. Nilai pada pengukuran kinerja yang dilaporkan secara luas untuk tujuan akuntabilitas (Ammons, 2007). Chan \& Gao (2007) menyatakan bahwa pengukuran kinerja sebagai alat dalam meningkatkan akuntabilitas.

\section{Hubungan Implementasi Akuntansi Berbasis Akrual dengan Akuntabilitas Keuangan Daerah}

Basis akuntansi yang dianut dalam penyajian laporan keuangan akan mempengaruhi penilaian kinerja keuangan. Basis akuntansi yang digunakan dalam penyajian laporan keuangan ada dua yaitu basis akrual dan basis kas. Menurut PSAP 01 basis akrual adalah basis akuntansi yang mengakui pengaruh transaksi dan peristiwa lainnya pada saat transaksi dan peristiwa itu terjadi, tanpa memperhatikan saat kas atau setara kas diterima atau dibayar. Sedangkan basis kas adalah basis akuntansi yang mengakui pengaruh transaksi dan peristiwa lainnya pada saat kas atau setara kas diterima atau dibayar.

Dalam PSAK 01 Perusahaan harus menyusun laporan keuangan atas dasar akrual, kecuali laporan arus kas. Sedangkan PSAP 01 basis akuntansi yang digunakan dalam laporan keuangan pemerintah yaitu basis kas untuk pengakuan pendapatan, belanja, transfer, dan pembiayaan dan basis akrual untuk pengakuan aset, kewajiban, dan ekuitas dana.

Basis akuntansi yang digunakan pada PP 24 Tahun 2005 tersebut adalah basis kas untuk pendapatan, belanja, dan pembiayaan; basis akrual untuk aset, kewajiban dan ekuitas, atau secara keseluruhan dikenal sebagai basis "cash toward accrual". Sementara itu pasal 70 ayat 2 Ketentuan Peralihan Undang-Undang Nomor 1 Tahun 2004 tentang Perbendaharaan Negara, menetapkan bahwa pengakuan dan pengukuran pendapatan dan belanja berbasis akrual diterapkan selambat-lambatnya pada tahun anggaran 2008.

\section{Pengembangan Hipotesis}

Pengaruh Implementasi Akrual Basis pada Sistem Akuntansi Pemerintah terhadap Rasio Efisiensi (OROE)

Rasio efisiensi menurut Cohen (2006)

adalah Total Operating Revenue To Operating Expense (OROE). Semakin besar Total Operating Revenue dibanding Total Operating Expense, maka semakin tinggi tingkat efisiensi suatu pemerintah daerah. Dalam rangka mengadopsi akuntansi berbasis akrual pencatatan pembayaran atas piutang pajak tahun lalu dengan basis kas dicatat sebagai pendapatan periode saat ini, hal ini akan menambah besarnya pendapatan periode ini. Tetapi secara akrual tidak boleh dicatat sebagai pendapatan periode ini karena transaksi ini akan berpengaruh terhadap besarnya aktiva lancar yaitu berkurangnya piutang pajak dan manambah rekening kas.

Dari uraian di atas dapat disimpulkan bahwa pendapatan dengan basis akrual dicatat cenderung lebih kecil sedangkan biaya dicatat cenderung lebih besar. Dengan kata lain, dengan semakin tinggi pemerintah daerah mengimplentasi akuntanti berbasis akrual, maka rasio OROE juga akan semakin 
turun. Hal ini mengindikasikan efisiensi pemerintah daerah semakin berkurang.

Berdasarkan logika teori tersebut di atas, maka hipotesis pertama dalam penelitian ini adalah sebagai berikut:

H1 : Implementasi akuntansi berbasis akrual pada Sistem Akuntansi Pemerintah berpengaruh terhadap Rasio Efisiensi (OROE)

Pengaruh Implementasi Akrual Basis pada Sistem Akuntansi Pemerintah terhadap Rasio Pemanfaatan Aktiva (TA/ROA)

Akuntabilitas atas pengelolaan seluruh aktiva ditunjukkan dengan rasio profitabilitas. Rasio profitabilitas menurut Cohen (2006) diukur dengan return on assets (ROA) rasio ini menunjukkan bahwa semakin tinggi ROA mengindikasikan bahwa dengan memanfaatkan aktivanya semaksimal mungkin, pemerintah daerah mampu menghasilkan surplus yang semakin tinggi.

Dari uraian di atas dapat disimpulkan bahwa pendapatan dengan basis akrual dicatat cenderung lebih kecil sedangkan biaya dicatat cenderung lebih besar. Hal ini akan berakibat terhadap surplus yang dihasilkan akan cenderung lebih rendah, sehingga ROA yang dihasilkan cenderung rendah. Jadi dengan mengimplementasi akuntansi berbasis akrual akan berakibat pada rendahnya ROA.

Berdasarkan logika teori tersebut di atas, maka hipotesis pertama dalam penelitian ini adalah sebagai berikut:

$\mathrm{H} 2$ : Implementasi akuntansi berbasis akrual pada Sistem Akuntansi Pemerintah berpengaruh terhadap Rasio Pemanfaatan Aktiva (ROA)

Pengaruh Implementasi Akrual Basis pada Sistem Akuntansi Pemerintah terhadap Rasio Likuiditas (CR)
Rasio likuiditas menurut Cohen (2006) diukur dengan current ratio (CR) rasio ini menunjukkan kemampuan pemerintah daerah dalam memenuhi kewajiban lancar dengan aktiva lancar yang dimiliki. Dengan demikian semakin tinggi CR menunjukkan bahwa aktiva lancarnya semakin tinggi yang berarti pemerintah daerah tidak mengalami kesulitan dalam membayar kewajiban jangka pendeknya. Dengan melakukan pencatatan berbagai rekening akrual misalnya piutang, persekot/biaya dibayar dimuka dan akun akrual yang lain kedalam neraca terutama dalam aktiva lancar, maka CR akan semakin tinggi.

Berdasarkan logika teori tersebut di atas, maka hipotesis pertama dalam penelitian ini adalah sebagai berikut:

H3 : Implementasi akuntansi berbasis akrual pada Sistem Akuntansi Pemerintah berpengaruh terhadap Rasio Likuiditas (CR)

Pengaruh Implementasi Akrual Basis pada Sistem Akuntansi Pemerintah terhadap Rasio Solvabilitas (LA)

Akuntabilitas atas pengelolaan seluruh aktiva dan kewajibannya ditunjukkan dengan rasio solvabilitas. Rasio solvabilitas menurut Cohen (2006) dengan long term liabilities to total assets (LA) rasio ini menunjukkan kemampuan pemerintah daerah dalam memenuhi seluruh utang jangka panjangnya dengan total aktiva yang dimiliki.

Berdasarkan logika teori tersebut di atas, maka hipotesis pertama dalam penelitian ini adalah sebagai berikut:

H4 : Implementasi akuntansi berbasis akrual pada Sistem Akuntansi Pemerintah berpengaruh terhadap Rasio Solvabilitas (LA)

\section{Model Penelitian}


Penelitian ini akan menguji pengaruh implementasi Akuntansi berbasis akrual pada SAP terhadap akuntabilitas Keuangan Daerah Wilayah Sumatera, dimana variabel independen adalah implementasi akuntansi berbasis akrual pada Sistem Akuntansi Pemerintah, Sedangkan variabel dependen dalam penelitian ini adalah akuntabilitas keuangan daerah yang diukur dengan Rasio Efisiensi (OROE), Rasio Pemanfaatan Aktiva (ROA), Rasio Likuiditas (CR), Rasio Solvabilitas (LA).

Berdasarkan uraian di atas kerangka pikir dalam penelitian ini dapat dilihat pada

Gambar 2.1 sebagai berikut:

\begin{tabular}{|l|l|}
\hline $\begin{array}{l}\text { Implementasi } \\
\text { Akuntansi }\end{array}$ & $\begin{array}{l}\text { Akuntabilitas Keuangan } \\
\text { Daerah: } \\
\text { Rasio Efisiensi (OROE) } \\
\text { Rasio Pemanfaatan Aktiva }\end{array}$ \\
\hline
\end{tabular}

\section{Gambar 2.1 Model Penelitian}

\section{Metode Penelitian}

Variabel Dependen dan Independen

Variabel dalam penelitian ini adalah akuntabilitas keuangan daerah. Salah satu alat untuk menilai akuntabilitas keuangan daerah adalah pengukuran kinerja keuangan daerah. Dalam penelitian ini pengukuran kinerja keuangan daerah menggunakan indikator pengukuran kinerja keuangan pemerintah daerah yang dikemukakan oleh Cohen (2006) yang terdiri dari:

a. Rasio Efisiensi

Operating Revenues To Operating Expense merupakan perbandingan antara jumlah pendapatan operasi dengan jumlah belanja operasi dalam satu periode tertentu. Menurut Cohen (2006) formula yang digunakan untuk menghitung rasio ini adalah sebagai berikut:

$$
\begin{aligned}
& \text { OROE } \\
& =\frac{\text { Total Operating Revenues }}{\text { Operating Expense }}
\end{aligned}
$$

b. Rasio Profitabilitas

Return on Assets merupakan perbandingan antara surplus dengan jumlah assets dalam satu periode tertentu. Menurut Cohen (2006) formula yang diagunakan untuk menghitung rasio ini adalah sebagai berikut:

$$
R O A=\frac{\text { Net Surplus/Deficit }}{\text { Total Asset }}
$$

\section{c. Rasio Likuiditas}

$$
\text { Rasio likuiditas yang }
$$
digunakan dalam penelitian ini adalah current ratio yaitu perbandingan antara jumlah harta lancar yang dimiliki pemerintah dengan jumlah total utang lancarnya. Rasio ini menggambarkan kemampuan pemerintah dalam menjamin utang lancar dengan harta lancer pemerintah daerah. Menurut Cohen (2006) formula yang diagunakan untuk menghitung rasio ini adalah sebagai berikut:

$$
C R=\frac{\text { Current Assets }}{\text { Current Liabilities }}
$$

d. Rasio Solvabilitas

\section{Long Term Liabilities To}

Total Assets merupakan indikator keuangan yang menggambarkan kemampuan pemerintah daerah dalam memenuhi seluruh utang jangka panjangnya dengan total 
aktiva yang dimiliki. Menurut Cohen (2006) formula yang diagunakan untuk menghitung rasio ini adalah sebagai berikut:

LA $=\frac{\text { Long Term Liabilitie }}{\text { Votal Assets }}$ penelitian ini adalah adopsi akuntansi berbasis akrual yang terdiri dari completeness, valuation, classification, mechanical accuracy, disclosure, formalistic requirements dan Adequacy and Usefulness. Dalam mengukur variabel ini menggunakan elements of compilancelaccounting index (Christiaens, 1999) yang disesuaikan dengan kondisi di Indonesia dengan berpedoman pada SAP dan datanya dapat diakses dan tersedia di Laporan Keuangan Pemerintah Daerah. Masing-masing elemen diukur secara dikotomi.

\section{Metode dan Desain Penelitian}

Metode penelitian yang digunakan adalah metode kuantitatif dengan menguji pengaruh implementasi akuntansi berbasis akrual pada Sistem Akuntansi Pemerintah terhadap Rasio Efisiensi (OROE), Profitabilitas (ROA), Likuiditas (CR), dan Solvabilitas (LA).

Penelitian ini menggunakan data sekunder. Data diperoleh dari download hasil pemeriksaan laporan keuangan oleh Badan Pemeriksa Keuangan Republik Indonesia (BPK RI) pada website www.bpk.go.id. Penelitian ini bertujuan menguji hipotesis (hypothesis testing) yaitu menguji hipotesis yang telah dirumuskan di awal. Penelitian ini merupakan penelitian poleed. Penelitian poleed adalah penelitian yang menggabungkan antara times series dan cross section. Times series adalah penelitian yang menggunakan dimensi satu waktu sedangkan cross section adalah penelitian yang menggunakan beberapa objek penelitian.

\section{Sumber Data dan Sampel Penelitian}

Sumber data dalam penelitian ini adalah data sekunder (secondary data) yaitu teknik pengumpulan data yang dapat digunakan adalah teknik pengumpulan data dari basis data. Data sekunder tersebut adalah data Laporan keuangan pemerintah daerah tahun 2015 - 2017 yang disusun berdasarkan Pernyataan Standar Akuntansi Pemerintah (PSAP). Data dalam penelitian ini dikumpulkan dari catatan atau basis data baik berupa hardcopy maupun softcopy yang diperoleh dari website resmi Badan Pemeriksa Keuangan Republik Indonesia (BPK RI).

Populasi dalam penelitian ini adalah seluruh laporan keuangan daerah (LKPD) yang disusun oleh pemerintah daerah wilayah Sumatera dan dipulikasi melalui website www.bpk.go.id.

Teknik pengambilan sampel yang digunakan pada penelitian ini menggunakan purposive sampling. Penelitian ini menggunakan kriteria pengambilan sampel seperti berikut ini:

a. Laporan keuangan pemerintah daerah yang diterbitkan pada tahun 2015 2017 dan dipublikasikan dalam situs resmi BPK.

b. Laporan keuangan pemerintah daerah wilayah Sumatera tahun 2015 - 2017 yang mencantumkan data dan informasi untuk pengukuran dan analisis variabel penelitian.

c. Laporan keuangan pemerintah daerah yang diterbitkan pada tahun 2015 2017 dengan opini audit wajar tanpa pengecualian, wajar tanpa pengecualian dengan bahasa atau paragrap penjelas maupun wajar dengan pengecualian. 
d. Hipotesis empat : Implementasi Akuntansi Berbasis Akrual berpengaruh terhadap LA $\mathrm{LA}=\beta 0+\beta 1$ Imply $+\mathrm{e}$

Keterangan:

LA = Long Term Liabilities to Total Assets

IMPLY = Implementasi Akuntansi Berbasis Akrual

Hasil Penelitian dan Pembahasan

Rekapitulasi hasil pengujian hipotesis pertama sampai hipotesis keempat adalah sebagai berikut

Tabel 1.

Rekapitulasi Hasil Pengujian Hipotesis

H1: OROE $=\beta 0+\beta 1 I m p l y+e$

$\mathrm{H}_{2}: \mathrm{ROA}=\beta 0+\beta 1 \mathrm{Imply}+\mathrm{e}$

$\mathrm{H}_{3}: \mathrm{CR}=\boldsymbol{\beta 0}+\boldsymbol{\beta 1} \mathrm{Imply}+\mathrm{e}$

H4: $\mathbf{L A}=\beta 0+\beta 1$ Imply+e

$*$ Signifikan pada $\mathrm{a}=5 \%$

$* *$ Signifikan pada $\mathrm{a}=10 \%$

Keterangan

$\begin{array}{ll}\text { ROA } & =\text { Return on Assets } \\ \mathrm{CR} & =\text { Current Ratio } \\ \mathrm{LA} & =\text { Long Term Liabilities toTotal } \\ \text { Assets } & \\ \text { OROE } \\ \text { Expenses }\end{array}$

Sumber: Data diolah sendiri (2018)

Berdasarkan tabel di atas dapat diketahui bahwa:

1. Implementasi akuntansi berbasis akrual pada Sistem Pemerintah secara statistik tidak berpengaruh terhadap OROE

2. Implementasi akuntansi berbasis akrual pada Sistem Pemerintah secara statistik berpengruh negatif terhadap ROA. Hal ini mendukung hipotesis kedua yaitu adopsi akuntansi berbasis akrual berpengaruh terhadap ROA.
3. Implementasi akuntansi berbasis akrual pada Sistem Pemerintah secara statistik berpengruh positif terhadap CR. Hal ini mendukung hipotesis ketiga, yaitu adopsi akuntansi berbasis akrual berpengaruh terhadap $\mathrm{CR}$.

4. Implementasi akuntansi berbasis akrual pada Sistem Pemerintah secara statistik berpengaruh positif terhadap LA. Hal ini mendukung hipotesis keempat yaitu adopsi akuntansi berbasis akrual berpengaruh terhadap LA.

\section{PEMBAHASAN}

Berdasarkan hasil penelitian sebagaimana terlihat dalam pengujian hipotesis diatas, berikut ini dikemukakan pembahasan mengenai hasil penelitian.

1. Pengujian hipotesis pertama menunjukkan bahwa tidak terdapat pengaruh signifikan antara adopsi akuntansi berbasis akrual terhadap total operating revenue to total operating expense.

2. Pengujian hipotesis kedua menunjukkan bahwa adopsi akuntansi berbasis akrual berpengaruh negatif terhadap return on assets (ROA). Hasil pengujian ini mendukung hipotesis yang diajukan, rasio ini menunjukkan bahwa semakin tinggi ROA mengindikasikan bahwa dengan memanfaatkan aktivanya semaksimal mungkin, pemerintah daerah mampu menghasilkan surplus yang semakin tinggi. Namun surplus yang tinggi belum menjamin kinerja pemerintah tersebut baik, karena dalam pemerintah daerah yang memiliki jumlah surplus harus dikembalikan ke kas negara dan untuk periode berikutnya hanya diperbolehkan mengajukan anggaran sebesar 
realisasi tahun sebelumnya. Hal ini dapat menghambat pertumbuhan pemerintah daerah karena tidak dapat memanfaatkan surplus yang mereka peroleh untuk membiayai pembangunan pada periode berikutnya.

Dalam rangka mengadopsi akuntansi berbasis akrual pencatatan pembayaran atas piutang pajak tahun lalu dengan basis kas dicatat sebagai pendapatan periode saat ini, hal ini akan menambah besarnya pendapatan periode ini. Tetapi secara akrual tidak boleh dicatat sebagai pendapatan periode ini karena transaksi ini akan berpengaruh terhadap besarnya aktiva lancar yaitu berkurangnya piutang pajak dan manambah rekening kas. Jadi pencatatan dengan basis akrual pendapatan periode ini akan cenderung lebih kecil dibanding dengan pencatatan dengan basis kas. Demikian juga dengan pencatatan biaya, biaya depresiasi, biaya kerugian atas piutang yang tidak tertagih, biaya kerugiannya lainnya. Biaya-biaya tersebut dalam akuntansi berbasis kas tidak dicatat sedangkan di dalam basis akrual biaya-biaya tersebut seharusnya dicatat. Hal ini akan berpengaruh biaya dengan basis akrual cenderung dicatat lebih besar daripada biaya dengan basis kas.

Dari uraian di atas dapat disimpulkan bahwa pendapatan dengan basis akrual dicatat cenderung lebih kecil sedangkan biaya dicatat cenderung lebih besar. Hal ini akan berakibat terhadap surplus yang dihasilkan akan cenderung lebih rendah, sehingga ROA yang dihasilkan cenderung rendah. Jadi dengan mengadopsi akuntansi berbasis akrual akan berakibat pada rendahnya ROA.

3. Pengujian hipotesis ketiga menunjukkan bahwa adopsi akuntansi akuntansi berbasis akrual berpengaruh positif terhadap current ratio (CR). Hasil pengujian ini mendukung hipotesis yang diajukan, Dengan demikian semakin tinggi CR menunjukkan bahwa aktiva lancarnya semakin tinggi yang berarti pemerintah daerah tidak mengalami kesulitan dalam membayar kewajiban jangka pendeknya. Dengan melakukan pencatatan berbagai rekening akrual/deferal akrual misalnya piutang, persekot/biaya dibayar dimuka dan akun akrual yang lain kedalam neraca terutama dalam aktiva lancar, maka akan menambah besarnya aktiva lancar. Semakin besarnya aktiva lancar, maka CR akan semakin tinggi.

4. Pengujian hipotesis keempat menunjukkan bahwa adopsi akuntansi akrual berpengaruh negatif terhadap long term liabilities to total assets (LA). Hasil pengujian ini mendukung hipotesis yang diajukan, rasio ini menunjukkan kemampuan pemerintah daerah dalam memenuhi seluruh utang jangka panjangnya dengan total aktiva yang dimiliki Dalam rangka mengadopsi akuntansi berbasisakrual perlu melakukan pencatatan atas piutang, persekot/biaya dibayar dimuka dan akun akrual yang lain. Dengan mencatat akun piutang, persekot/biaya dibayar dimuka dan akun akrual yang lain nilai aktiva yang disajikan dalam necara cenderung lebih besar dari pada dengan pencatatan basis kas. Dengan 
mengadosi Akuntansi berbasis akrual, nilai aktiva akan menjadi lebih besar sehingga akan mengakibatkan rasio LA akan rendah, hal ini akan menimbulkan kesan bahwa pemerintah daerah mampu dalam membayar utang jangka panjangnya dengan memanfaatkan aktivanya.

\section{Kesimpulan dan Saran Kesimpulan}

Berdasarkan hasil analisis data dan pembahasan hipotesis dapat disimpulkan bahwa

1. Pengujian hipotesis pertama menunjukkan bahwa tidak terdapat pengaruh signifikan antara implementasi akuntansi berbasis akrual pada Sistem Pemerintah terhadap total operating revenue to total operating expense. Dengan demikian hasil penelitian ini tidak mendukung hipotesis yang pertama.

2. Pengujian hipotesis kedua menunjukkan bahwa implementasi akuntansi berbasis akrual pada Sistem Pemerintah berpengaruh negatif terhadap return on assets (ROA). Hasil pengujian ini mendukung hipotesis yang diajukan, rasio ini menunjukkan bahwa semakin tinggi ROA mengindikasikan bahwa dengan memanfaatkan aktivanya semaksimal mungkin, pemerintah daerah mampu menghasilkan surplus yang semakin tinggi. Namun surplus yang tinggi belum menjamin kinerja pemerintah tersebut baik, karena dalam pemerintah daerah yang memiliki jumlah surplus harus dikembalikan ke kas negara dan untuk periode berikutnya hanya diperbolehkan mengajukan anggaran sebesar tahun sebelumnya. Hal ini dapat menghambat pertumbuhan pemerintah daerah karena tidak dapat memanfaatkan surplus yang mereka peroleh untuk membiayai pembangunan pada periode berikutnya.

3. Pengujian hipotesis ketiga menunjukkan bahwa implementasi akuntansi berbasis akrual pada Sistem Pemerintah berpengaruh positif terhadap current ratio (CR). Hasil pengujian ini mendukung hipotesis yang diajukan, Dengan demikian semakin tinggi $\mathrm{CR}$ menunjukkan bahwa aktiva lancarnya semakin tinggi yang berarti pemerintah daerah tidak mengalami kesulitan dalam membayar kewajiban jangka pendeknya.

4. Pengujian hipotesis keempat menunjukkan bahwa implementasi akuntansi berbasis akrual pada Sistem Pemerintah berpengaruh negatif terhadap long term liabilities to total assets (LA). Hasil pengujian ini mendukung hipotesis yang diajukan, rasio ini menunjukkan kemampuan pemerintah daerah dalam memenuhi seluruh utang jangka panjangnya dengan total aktiva yang dimiliki. Dalam rangka mengadopsi akuntansi berbasis akrual pencatatan akun akrual yang terkait dengan aktiva adalah sangat penting, karena akun akrual tersebut merupakan kekayaan pemerintah daerah yang dapat digunakan untuk melunasi utang jangka panjangnya.

\section{Saran}

Berdasarkan hasil penelitian dapat diberikan beberapa saran untuk berbagai pihak, yaitu: 
1. Hasil penelitian memberikan informasi bahwa adopsi akuntansi berbasis akrual di tingkat Kabupaten/Kota masih relatif kecil, sehingga perlu adanya upaya yang lebih intens dari KSAP untuk dalam hal perbaikan standar dan sosialisasi mengenai implementasi akuntansi berbasis akrual di sektor publik sehingga dapat menjadi salah satu sarana pendukung yang diperlukan dalam rangka transparansi dan akuntabilitas pemerintah.

2. Hasil penelitian ini memberikan informasi bahwa akuntansi berbasis akrual berpengaruh negatif terhadap return on assets hal ini dikarenakan adanya suatu aturan yang mengharuskan adanya pengembalian surplus ke kas negara disamping itu pemerintah daerah hanya boleh mengajukan anggaran sebesar realisasi tahun sebelumnya. Hal ini akan mengakibatkan adanya kecenderungan dari pemerintah daerah untuk menghabiskan surplus dengan kegiatan yang sebenarnya kurang bermanfaat. Dengan demikian hendaknya pemerintah pusat memberikan kebijakan mengenai pengelolaan surplus oleh pemerintah daerah.

Akuntabilitas adalah kewajiban untuk memberikan pertanggungjawaban atau untuk menjawab dan menerangkan kinerja dan tindakan seseorang/pimpinan organisasi kepada pihak yang memiliki hak atau kewenangan untuk meminta pertanggungjawaban atau keterangan. Semakin banyaknya laporan keuangan yang beropini tidak wajar dan disclaimer dari tahun ke tahun menandakan bahwa akuntabilitas keuangan kita juga masih buruk, sehingga banyak hal yang harus dilakukan oleh pemerintah daerah yang bersangkutan diantaranya mencakup sistem pembukuan, sistem aplikasi teknologi komputer, inventarisasi aset dan utang, jadwal waktu penyusunan laporan keuangan dan pemeriksaan serta pertanggungjawaban anggaran, quality assurance atas Laporan Keuangan Pemerintah Daerah oleh pengawas intern dan sumber daya manusia.

\section{DAFTAR PUSTAKA}

Ammons, David N. 2007. Performance Masurement: A Tool For Accountability and Performance Improvement. The University of North California at Chapel Hill.1-12

Barrett, Pat. 2004. Financial Management in the Public Sector - How Accrual Accounting and Budgeting Enhances Governance and Accountability. CPA Forum.

Beechy, T. H., 2007. Does Full Accrual Accounting Enhance Accountability?. The Innovation Journal: The Public Sector Innovation Journal, 12(3): 1- 18

Champoux, M., 2006. Accrual Accounting in New Zealand and Australia: Issues and Solutions. Briefing Paper No. 27: $1-24$

Chan, Hon S dan Gao, Jie. 2007. Putting The Cart Before the Horse: Accountability or Performance? Department of Public and Social Administration City University. Hong Kong

Christiaens, J., 1999. Financial Accounting Reform in Flemish Municipalities: An Empirical Investigation. Financial Accountability \& Management. 15 (1): 0267-4424

Cohen, S. 2006. Indetifying the moderator factors of financial performance in Greek Municipalities. Annuall 
Conference. 5th. HFAA. Thessaonica.

Federation Des Experts Comptables Europeens (FEE), 2006. Accrual Accounting for More Effective Public Policy.

Guthrie, J., 1998. Application of Accrual Accounting in The Australian Public Sector - Rethoric or Reality?. Financial Accountability \& Management, 14 (1): 1-18

Kim, Pan Suk. 2008. Enhancing Public Accountability through Public Sector Reform: a Perspective from Developing Countries. A draft prepared for delivery at National Taiwan University on May 8.

KSAP, 2006. Memorandum Pembahasan Penerapan Basis Akrual Dalam Akuntansi Pemerintahan Di Indonesia. Jakarta.

Mardiasmo. 2006. Pewujudan Transparansi dan Akuntabilitas Publik Melalui Akuntansi Sektor Publik: Suatu Sarana Good Governance. Jurnal Akuntansi Pemerintah 2 (1): 1 - 17

Monsen, N., 2002. The Case for Cameral Accounting.

Financial Accountability \& Management, 18 (1): 25-38

Mustofa, H., 2006. Basis Akuntansi Pemerintahan. January 30. Available at http://abusyadza.wordpress.com/

Ryan, Robinson, Grigg. 2000. Financial Performance Indicators For Australian Local Governments. Accounting, Accountability and Performance 6 (2): 89-106. Sadjiarto, Arja. 2000. Akuntabilitas dan Pengukuran Kinerja Pemerintahan. Jurnal Akuntansi \& Keuangan. 2 (2):138-150

Siswandari. 2002. Statistika Terapan Bagi Para Peneliti. Surakarta: UNS Press.
Solihin. 2007. Penerapan Good Governance di Sektor Publik untuk Meningkatkan Akuntabilitas Kinerja Lembaga Publik. Available at http://www.slideshare.net/DadangSol ihin/penerapan-good-gover-nance disektorpublik-untuk-meningkatkanakuntabilitas-kinerja-lembaga-publik Supriyono, B. 2000. Responsivitas dan Akuntabilitas Sektor Publik. http://www.akademik.unsri.ac.id/download/j ournal/files/brapub/4Responsivitas\%2\&\%20 Akuntabilitas\%20Sektor\%20PublikBambang\%20Supri\%85.pdf 